\title{
ЕТИКО-ПРОФЕСІЙНІ АСПЕКТИ ФОРМУВАННЯ СОЦІАЛЬНО-ПСИХОЛОГІЧНИХ ХАРАКТЕРИСТИК ОСОБИСТОСТІ МЕДСЕСТРИ В УМОВАХ АТО
}

\author{
О. Н. Литвинова, О. Ю. Мезенцева \\ ДВНЗ «Тернопільський державний медичний університет \\ імені I. Я. Горбачевського МОЗ Украӥни" \\ Комунальна медична установа «Міська лікарня № 1» М. Краматорськ
}

\begin{abstract}
У даній статті показано необхідність і алгоритм дослідження системи формування психологічних, соціальних та етичних аспектів роботи середнього медичного персоналу в процесі підготовки до роботи в зоні АТО та в інших екстремальних умовах.
\end{abstract}

\section{ETHICAL AND PROFESSIONAL ASPECTS OF FORMATION OF SOCIO-PSYCHOLOGICAL CHARACTERISTICS OF NURSES UNDER ATO}

\author{
O. N. Lytvynova, 0. Y. Mezentseva \\ I. Horbachevsky Ternopil State Madical University \\ Municipal Health Care Facility “City hospital №1», Kramatorsk
}

This article shows the need for algorithm research and system of formation of psychological, social and ethical aspects of nursing staff in preparation for work in the area of ATO and other extreme conditions.

Вступ. Історія українських збройних формувань містить у своєму літописі чимало прикладів тісної взаємодії військових та медичних чинників. Питання медсестринської опіки військовослужбовців в Україні набуває все більшої важливості та актуальності у зв'язку з гібридною війною, що розв'язана сепаратистами за підтримки путінського режиму Російської Федерації. Присутність медсестри в зоні бойових дій та на звільнених українськими військовими територіях необхідна для моральної та духовної підтримки як військовослужбовців, так і мирних громадян України.

Водночас слід відмітити, що сьогодні у цьому проблемному регіоні держави катастрофічно бракує кваліфікованих медичних сестер, що зумовлено як неймовірно низькою заробітною платою, і, як наслідок, низькою соціальною цінністю медсестри, так і незадовільними соціальними умовами праці. Парадокс ситуації полягає у тому, що індивідуальне ставлення до медсестри у випадку вимушеного контакту із нею через хворобу чи поранення кардинально відрізняється від соціального ставлення. Саме цим питанням і присвячена наша робота.

(с) О. Н. Литвинова, О. Ю. Мезенцева, 2017
Основна частина. Основним завданням у класичній сфері професійного формування медсестер $\epsilon$ виховання і навчання творчої, неординарно мислячої, гармонійної й духовно розвиненої особистості, здатної діяти в різноманітних умовах суспільного і державного життя. Одним із найважливіших завдань при підготовці медсестер для роботи в екстремальних ситуаціях $є$ формування у неї споконвічних моральних й культурних цінностей українського народу (колективізм, повагу до людини і природи, прагнення до максимальної творчої самовіддачі, високодуховних цінностей) [1].

В основі формування японської медичної сестри закладений принцип «кокоро», який українською мовою перекладається як серце, душа, розум, менталітет, гуманність. У зміст «кокоро» включається повага до людей і тварин, симпатія і великодушність до інших людей, пошук істини, здатність відчувати прекрасне й піднесене, мати самоконтроль, зберігати природу, робити внесок у розвиток суспільства [2].

В Україні стереотипне уявлення про медсестру включає аналогічні риси. Підтвердженням цих уявлень $є$ зображення образу медсестри у літературі, 
художніх фільмах, живописних полотнах тощо. На сьогодні немає розроблених доступних методик для виміру душевності, гуманності, доброти, ступеня емпатії тощо, які можна було б використовувати як критерій відбору при вступі до навчального закладу чи при прийомі на роботу [3]. Тому саме формування цих рис у процесі навчання і підтверджують актуальність нашого дослідження, метою якого було дослідження етико-професійних аспектів формування соціальнопсихологічних характеристик особистості медсестри для успішної їі діяльності в умовах АТО.

В основу своєї роботи ми поклали портретну характеристику медсестри з позицій бачення поранених у зоні АТО. Передбачалось отримання тих рис, які очікують самі поранені від медсестри як в умовах службових буднів, так і в умовах критичного стану їхнього життя - у випадку поранення.

Вивчення соціально-психологічного портрету медсестри за баченням колег у зоні АТО дає можливість вивести ті особливі професійні риси, що потребують формування при підготовці такого персоналу. Також такий підхід дає можливість виокремити такі риси, які в екстремальних умовах АТО дозволять створити найоптимальніший професійний клімат взаємодії та наступництва серед медперсоналу. Отримана в результаті опитування інформація дозволить сформувати соціально-психологічні характеристики особистості медсестри, які необхідно буде сформувати в умовах підготовки до роботи в зоні АТО або в інших екстремальних ситуаціях. Визначений інтеграційний соціально-психологічний портрет медсестри має сформуватися в процесі підготовки до роботи в зоні ATO.

Для вивчення даних питань ми сформували анкетний лист із переліком тестових запитань для виявлення тих особливих соціально-психологічних рис, які необхідні будуть медичній сестрі в умовах роботи в зоні АТО.

ОПИТУВАЛЬНИЙ ЛИСТ - АНКЕТА

1. Як на Вашу думку, чи повинна медична сестра у своїх діях в екстремальних умовах керуватися виключно розумом і логікою?

А. Так, завжди.

В. Лише в межах ії обов'язків.

C. Ні, вона повинна керуватися насамперед співчуттям.

D. Лише в критичних випадках.

E. Не знаю.

F. Ваш варіант відповіді
2. Якою мірою медсестра повинна вміти висловлювати свої думки в умовах АТO?

А. Вона повинна формулювати думки максимально стисло і чітко.

В. Вона не повинна висловлювати свої думки, че функція лікаря і командира.

C. Вона є виконавцем розпоряджень, а не філософом.

D. Вона повинна висловлювати свої думки вільно $i$ зрозуміло.

Е. Вона повинна мати творче мислення і вміти коректно викладати свої думки.

F. Ваш варіант відповіді

3. Чи є прямими функціональними обов'язками медсестри уміння брати на себе ризик і відповідальність в умовах АТО?
А. Так, звичайно.
В. Лише коли їй доручать такі дії.
C. Лише у критичних ситуачіях.
D. Ні в якому випадку, для цього є командири.
E. Медсестра не може ризикувати.
F. Ваш варіант відповіді

4. Медсестра повинна проводити маніпуляції та процедури з відчуттям впевненості у собі та з вираженим співчуттям до хворого?

A. Впевненість необхідна медсестрі.

B. Співчуття і впевненість несумісні.

C. Ці почуття залежать від стану здоров'я пачієнта.

D. Чим більше виражені чі почуття - тим краща медсестра.

Е. Це їі особиста справа і не регламентується обов'язками.

F. Ваш варіант відповіді

5. Забезпечуючи медччний догляд за хворими та пораненими, медсестра повинна володіти гострою інтуїцією та проникливістю?
А. Так, звичайно.
В. Лише коли пацієнт не заперечує.
C. Лише зі згоди керівництва.
D. Лише у складних випадках.
E. Частково.
F. Ваш варіант відповіді

6. Медсестра повинна проявляти більше гнучкість чи наполегливість при виконанні своїх обов'язків?

А. Залежно від ситуації.

B. Наполегливість лише при відсутності лікаря.

C. Ці риси характеру несумісні.

D. Наполегливість при наданні допомоги при невідкладних станах.

Е. Гнучкість стосовно хворого, але не пораненого. 
F. Ваш варіант відповіді

\section{7. Медсестра має проявляти сміливість?}

А. Так, завжди.

B. Лише ту, яка стосується ії роботи.

C. Це функції військовослужбовців.

D. Лише в екстремальних ситуаціях.

E. Їй че не потрібно.

F. Ваш варіант відповіді

8. Чи потрібні медсестрі вміння організовувати поширення медичних знань щодо профілактики захворювань та їх ускладнень?

А. Так, постійно.

B. Лuше при нагоді.

С. Це функції санітарно-освітньої діяльності лікаря.

D. Лише коли хворі чи поранені звертаються за такою консультацією.

Е. Коли їй доручають прочитати таку лекцію.

F. Ваш варіант відповіді

9. Чи може медсестра самостійно приймати рішення в межах своєї компетенції?

А. Так, це ї̈ право.

В. Лише в екстремальних випадках.

С. Ні, вона лише виконує вказівки лікаря.

D. Лише при відсутності лікаря.

Е. Лише коли є загроза життю хворого чи пораненого.

F. Ваш варіант відповіді

10. Чи потрібні медсестрі, в процесі її діяльності такі риси, як цікавість та здатність освоювати нові знання та вміння?

А. Так, у межах своєї компетенції.

В. Лише з власного сумління.

C. Це функції керівника.

D. Hi, в умовах АTO це недопустимо.

Е. Лише коли ці риси необхідні для виконання певноі роботи самотужки.

F. Ваш варіант відповіді

11. Чи несе медсестра відповідальність за неякісне ведення медичної документації та недостовірність інформації, що вноситься до неї?

A. В межах, визначених чинним законодавством України.

B. Несе лише за недостовірність інформації.

C. Hi, не несе.

D. Лище за допущені помилки.

E. В умовах АТО че особливо актуально.

F. Ваш варіант відповіді

12. Чи зобов'язана медсестра проявляти такт і дипломатичність при наданні невідкладної доnомоги?
А. Обов'язково.

В. До певної міри, головне - правильна методика маніпуляцій.

C. В умовах АТО часто не до дипломатії.

D. Ці риси обов'язкові не лише для медсестри.

Е. Тільки якщо вона працює палатною медсестрою в мирній зоні.

F. Ваш варіант відповіді

13. Відповідальність медсестри зумовлена насамперед такими рисами ії характеру, як (вкажіть у відсотках):

А. Обов'язковість.

B. Hеnохитність.

C. Вміння відстоювати свою позицію.

D. Bnepmicmь.

E. Cmpax.

F. Ваш варіант відповіді

14. Чи вважаєте Ви престижною професію медсестри в умовах АTO?
A. Так.
В. Більше так, ніж ні.
C. Більше ні, ніж так.
D. Hi.
E. Ваш варіант відповіді

15. Що із нижченаведеного є визначальним, на Вашу думку, в роботі середнього медичного персоналу в зоні АТО (вкажіть у відсотках)?
А. Професійний інтерес.
В. Можливість заробляння грошей.
C. Співчуття до хворих та поранених.
D. Можливість зробити кар'єру.
Е. Неможливість влаштуватись на іншу роботу.
F. Можливість нових знайомств.
G. Ваш варіант відповіді

16. які якості Ви вважаєте найголовніші для медсестри в умовах АТО (вкажіть у відсотках)?
A. Співчуттля.
В. Професійні знання.
C. Віртуозність у проведенні маніпулячій.
D. Витримка.
Е. Холодний розум.
F. Душевна теплота.
G. Ваш варіант відповіді

17. Які види заохочень Ви вважаєте найзначимішими для медсестри в умовах АТО (вкажіть у відсотках)?
А. Видача премії.
B. Цінні подарунки.
С. Почесні грамоти. 
D. Присвоєння почесного звання чи державних нагород.

Е. Подяка із занесенням у трудову книжку.

F. Душевна вдячність врятованих.

G. Ваш варіант відповіді

18. Які риси характеру Ви вважаєте найзначимішими для медсестри в зоні АТО (вкажіть у відсотках)?
А. Незалежність.
В. Самостійність.
С. Уміння кооперуватися.
D. Уміння змінювати себе.
Е. Прагнення до переваги.
F. Потреба в досягненнях.
G. Ваш варіант відповіді

19. Яка пріоритетність рис характеру, необхідних медсестрі в умовах АТО (вкажіть у відсотках)?
А. Холодний розум і витримка.
В. Уміння переконувати.
С. Уміння жартувати.

\section{СПИСОК ЛІТЕРАТУРИ}

1. Аверин В. А. Обзор основных теорий развития / В. А. Аверин // Психология человека от рождения до смерти ; под ред. А. А. Реана. - СПб., 2003. - С. 116-128.

2. Варій М. Й. Психологія особистості : навч. посіб. / М. Й. Варій. - К. : Центр учбової літератури, 2008. - 592 с.
D. Уміння самоорганізовуватись

Е. Випромінювати надійність.

F. Мати високу працездатність.

G. Ваш варіант відповіді

20. які риси характеру необхідні медсестрі для роботи в умовах АТО (вкажіть у відсотках)?
А. Урівноваженість.
B. Енергійність.
С. Владність.
D. Войовничість.
Е. Вміння опановувати себе.
F. Агресивність.
G. Ваш варіант відповіді

Висновок. Проведені дослідження дозволили проаналізувати психологічні, соціальні та етичні аспекти роботи середнього медичного персоналу та удосконалити систему формування тих необхідних рис у медсестри в процесі її підготовки до роботи в зоні АТО та в інших екстремальних умовах.

3. Горбатов Н. С. Практикум по психологическому исследованию : учеб. пособ. / Н. С. Горбатов. - Самара : Издательский дом «БАРАХ-М», 2003. - С. 141-146.

Отримано 10.01.17 